\title{
Rozwój mowy i komunikacji dziecka z uszkodzonym słuchem
}

\begin{abstract}
Magdalena Olempska-Wysocka, Rozwój mowy i komunikacji dziecka z uszkodzonym stuchem [Language and communication development of children with hearing impairment]. Interdyscyplinarne Konteksty Pedagogiki Specjalnej, nr 14, Poznań 2016. Pp. 115-135. Adam Mickiewicz University Press. ISSN 2300-391X

The article treats on complexity of speech development, communication process of child with damaged hearing. Article emphasizes factors defining different language and communication competences. Hearing impairment leads to self-expression being delayed. Mentioned delays, could be quantitative (active and passive vocabulary, subordinate to the chronological age of the child) and qualitative (numerous, different disorders of articulation, semantic errors, problems with understanding simple commands).
\end{abstract}

KEY WORDS: child with hearing impairment, deaf child, speech development, communication skills development, speech disorders

\section{Wprowadzenie}

Mowa dziecka to zagadnienie obejmujące swoim zakresem wszystkie zjawiska związane z komunikacją werbalną i niewerbalną dziecka - tj. procesy tworzenia i rozumienia wypowiedzi nazywane na gruncie psycholingwistyki czynnościami mowy. Kompetencja językowa i komunikacyjna stanowią podstawę czynności 
mowy, które są świadomymi działaniami nadawcy i odbiorcy. Świadomość językowa w wymiarze indywidualnym oraz społecznym przejawia dynamiczny charakter - podlega zmianom, które są uwarunkowane wewnętrznie (związane ze zmianami zachodzącymi w umyśle użytkownika języka) i zewnętrznie (zmiany zachodzące w środowisku społeczno-kulturowym). W obrębie danej społeczności językowej (komunikacyjnej) jest ona zróżnicowana i może zależeć np. od zróżnicowania wewnętrznego danej społeczności. W wymiarze indywidualnym świadomość uwarunkowana jest rolami, jakie jednostka odgrywa w obrębie danej społeczności językowej a także poza nią¹.

W toku przyswajania języka dziecko musi opanować funkcje reprezentatywną i komunikacyjną, a także opanować cztery składniki wiedzy językowej (fonologiczny, semantyczny, syntaktyczny i pragmatyczny). Wiedza językowa przejawia się poprzez percepcję mowy, rozumienie wypowiedzi innych osób, leżących u ich podstaw intencji oraz poprzez produkowanie, artykułowanie własnych wypowiedzi i wyrażanie intencji ${ }^{2}$. Dziecko prawidłowo rozwijające się ma możliwość naturalnego przyswajania mowy i komunikowania się dzięki przebywaniu od najwcześniejszych chwil życia w środowisku ludzi mówiących. Dzięki temu kojarzy dźwięki mowy z konkretnymi czynnościami, przedmiotami, sytuacjami. Z czasem zaczyna naśladować te dźwięki oraz odkrywa, że poprzez wypowiadanie słów może otrzymać daną rzecz, wyrazić swoje pragnienia itp. Następstwem uszkodzenia słuchu są wtórne trudności w nabywaniu komunikacyjnych umiejętności językowych, poznawaniu samego systemu językowego, a idąc dalej - następstw deprywacji językowej w rozwoju procesów poznawczych, zwłaszcza myślenia. Powstająca bariera fonologiczna warunkuje zablokowanie lub opóźnienie naturalnego procesu kształtowania się mowy

${ }^{1}$ J. Porayski-Pomsta, O rozwoju mowy dziecka. Dwa studia, Dom Wydawniczy Elipsa, Warszawa 2015, s. 21

2 I. Kurcz, Psychologia języka i komunikacji, Wydawnictwo Naukowe Scholar, Warszawa 2000. 
u dziecka z uszkodzonym słuchem. Uniemożliwia to lub ogranicza przyswajanie podsystemu języka stanowiącego o sposobie werbalnego kodowania znaczeń - podsystemu fonologicznego ${ }^{3}$.

\section{Etapy rozwoju mowy dziecka z uszkodzonym słuchem}

Rozwój mowy dzieci z uszkodzonym słuchem przebiega według tych samych etapów rozwojowych co rozwój mowy dzieci słyszących, ale w inny, charakterystyczny i specyficzny sposób ze względu na ograniczenia wynikające $\mathrm{z}$ występującej niepełnosprawności. Analizując możliwości rozwoju kompetencji językowej i komunikacyjnej dziecka $\mathrm{z}$ uszkodzonym słuchem, należy uwzględnić szereg czynników, które w różnym stopniu i w różnym zakresie wpływają na funkcjonowanie dziecka. Do najważniejszych należy zaliczyć:

- czas, w którym nastąpiło uszkodzenie słuchu - czy jest to wada wrodzona, czy nabyta, w jakim okresie rozwojowym wystąpiła; należy pamiętać, że mechanizmy zaburzeń mowy spowodowane przez uszkodzenie słuchu będą inne u osób niesłyszących od urodzenia (głuchota prelingwalna), inne u osób, u których utrata nastąpiła w trakcie rozwoju mowy (głuchota perilingwalna) i inne u osób, które utraciły słuch po opanowaniu języka (głuchota postlingwalna);

- czas zdiagnozowania uszkodzenia słuchu - im wcześniej nastąpi diagnoza tym lepsze rokowania i możliwości rozwoju wrażliwości słuchowej4;

- rodzaj uszkodzenia słuchu - czy jest przewodzeniowy, odbiorczy, mieszany;

- stopień uszkodzenia słuchu - który nie stanowi czynnika determinującego, ale w dużym stopniu wpływa na możliwości

${ }^{3}$ K. Krakowiak, Dar języka. Podręcznik metodyki wychowania językowego dzieci i młodzieży z uszkodzeniami narzadu stuchu, Wydawnictwo KUL, Lublin 2012.

${ }^{4}$ Ogromną rolę odgrywają tu przesiewowe badania słuchu, dzięki którym wada słuchu może zostać wykryta zaraz po urodzeniu. 
słuchowe odbioru mowy, a także ma wpływ na dalsze losy dziecka - np. wybór dotyczący metody komunikacji czy też np. formy kształcenia;

- liczbę występujących deficytów rozwojowych - czy uszkodzenie słuchu stanowi pojedynczą wadę, czy też występują dodatkowe zaburzenia rozwojowe powodujące niepełnosprawność sprzężoną;

- czas zaaparatowania lub/i zaimplantowania - im wcześniej, tym większe możliwości naturalnego rozwoju mowy, prozodii, a także wszystkich funkcji poznawczych ${ }^{5}$;

- czas rozpoczęcia kompleksowej rehabilitacji - terapii logopedycznej, surdopedagogicznej, psychologicznej, poprzez wykorzystanie naturalnych faz wrażliwości i plastyczności mózgu dziecka;

- przyczyny uszkodzenia słuchu - wrodzone, okołoporodowe, nabyte w późniejszym okresie życia;

- potencjał intelektualny dziecka;

- poziom rozwoju emocjonalnego dziecka;

- komunikację z otoczeniem - fakt, czy dziecko wychowuje się w środowisku osób słyszących, czy niesłyszących;

- współpracę rodziny i najbliższego otoczenia dziecka.

Efektywna i pomyślna komunikacja pomiędzy rodzicem i dzieckiem z uszkodzonym słuchem stanowi jeden $\mathrm{z}$ najważniejszych predyktorów rozwoju poznawczego dziecka. Brak naturalnych, spontanicznych aktów komunikacji stanowi najważniejszą konsekwencję niskiego poziomu możliwości językowych podopiecznego. Można jednoznacznie stwierdzić, że przyswajanie języka przez dziecko z uszkodzonym słuchem stanowi największe wyzwanie rozwojowe zarówno dla niego samego, jak i dla jego rodziców. Nie-

${ }^{5}$ Zgodnie z wytycznymi Join Committee on Infant Haring z 2007 r. oraz Europen Consensus Development Conference on Neonatal Hearing Screening z 1998 r. dotyczące wykrywania dysfunkcji słuchu pokazują, że do 1. miesiąca życia dziecko powinno mieć określony stopień ubytku słuchu, a do 6. miesiąca powinno być zaopatrzone w odpowiednio dobrane aparaty słuchowe/implanty ślimakowe, a także jak najwcześniej powinna być rozpoczęta rehabilitacja słuchu i mowy. 
słyszące dzieci wychowujące się wśród osób niesłyszących mają zdecydowanie większy dostęp do języka - poprzez naturalny, „wizualny" język. Ponadto, jak pokazują liczne badania ${ }^{6}$, wczesne stosowanie języka migowego w komunikacji niesłyszące dziecko niesłyszący rodzic stanowi pewnego rodzaju prewencję deprywacji językowej. Badania7 wskazują, że dzieci te przechodzą etapy rozwoju języka w takiej samej kolejności i w takich samych odstępach czasowych do drugiego roku życia. Po tym okresie nawet dzieci niesłyszące niesłyszących rodziców prezentują opóźniony rozwój mowy.

Dokonując charakterystyki rozwoju mowy dzieci z uszkodzonym słuchem, należy odnieść się do periodyzacji rozwoju mowy dzieci słyszących, jednakże nie jest możliwe jednoznaczne określenie etapów czasowych przez jakie przechodzi dziecko. Wiele czynników ponadto wpływa na mowę dziecka i nie pozwala na dokładne przewidywanie jego dalszego rozwoju. Jak wskazuje Kazimiera Krakowiak ${ }^{8}$, populacja osób z uszkodzonym słuchem nie jest grupą jednorodną, jest zróżnicowana pod względem rodzaju i nasilenia zaburzeń mowy, a także pod względem potrzeb edukacyjnych i komunikacyjnych.

${ }^{6}$ K. Cormier, A. Schembri, D. Vinson, E. Orfanidou, First language acquision differs from second language acquisition in prelingually deaf signers: Evidence from sensitivity to grammaticality judgement in British Sign Language, "Cognition" 2012, nr 124, s. 50-65; T. Humphries, P. Kushalnagar, G. Mathur, D.J. Napoli, C. Padden, C. Rathmann, S.R. Smith, Language acquisition for deaf children: Reducing the harms of zero tolerance to the use of alternative approaches, "Harm Reduction Journal" 2012, nr 9(1), s. 16; T. Humphries, P. Kushalnagar, G. Mathur, D.J. Napoli, C. Padden, C. Rathmann, S.R. Smith, Ensuring language acquisition for deaf children: What linguists can do, "Language" 2014, nr 90(2), s. e31-e52.

7 Zob. m.in.: J. Anderson, J. Reilly, The MacArthur Communicative Development Inventory: The normative data from American Sign Language, "Journal of Deaf Studies and Deaf Education" 2002, nr 7, s. 83-106; T. Woolfe, R. Herman, P. Roy, B. Woll, Early vocabulary development in deaf native signers: a British Sign Language adaptation of the communicative development inventories, "Journal of Child Psychology and Psychiatry" 2010 nr 51, s. 322-331.

${ }^{8}$ K. Krakowiak, Dar jezzyka. Podręcznik metodyki wychowania językowego dzieci i młodzieży z uszkodzeniami narządu stuchu, Wydawnictwo KUL, Lublin 2012. 


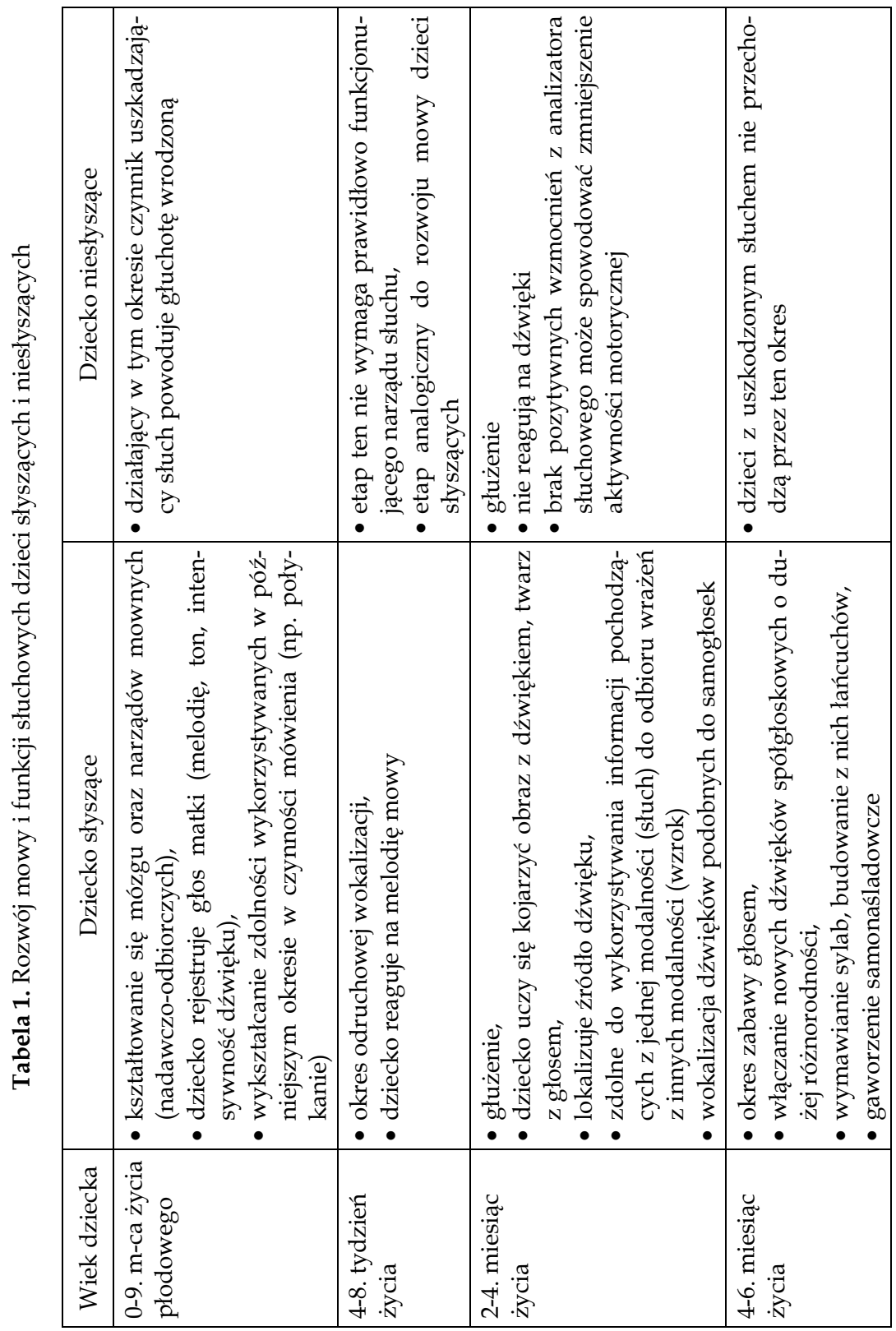




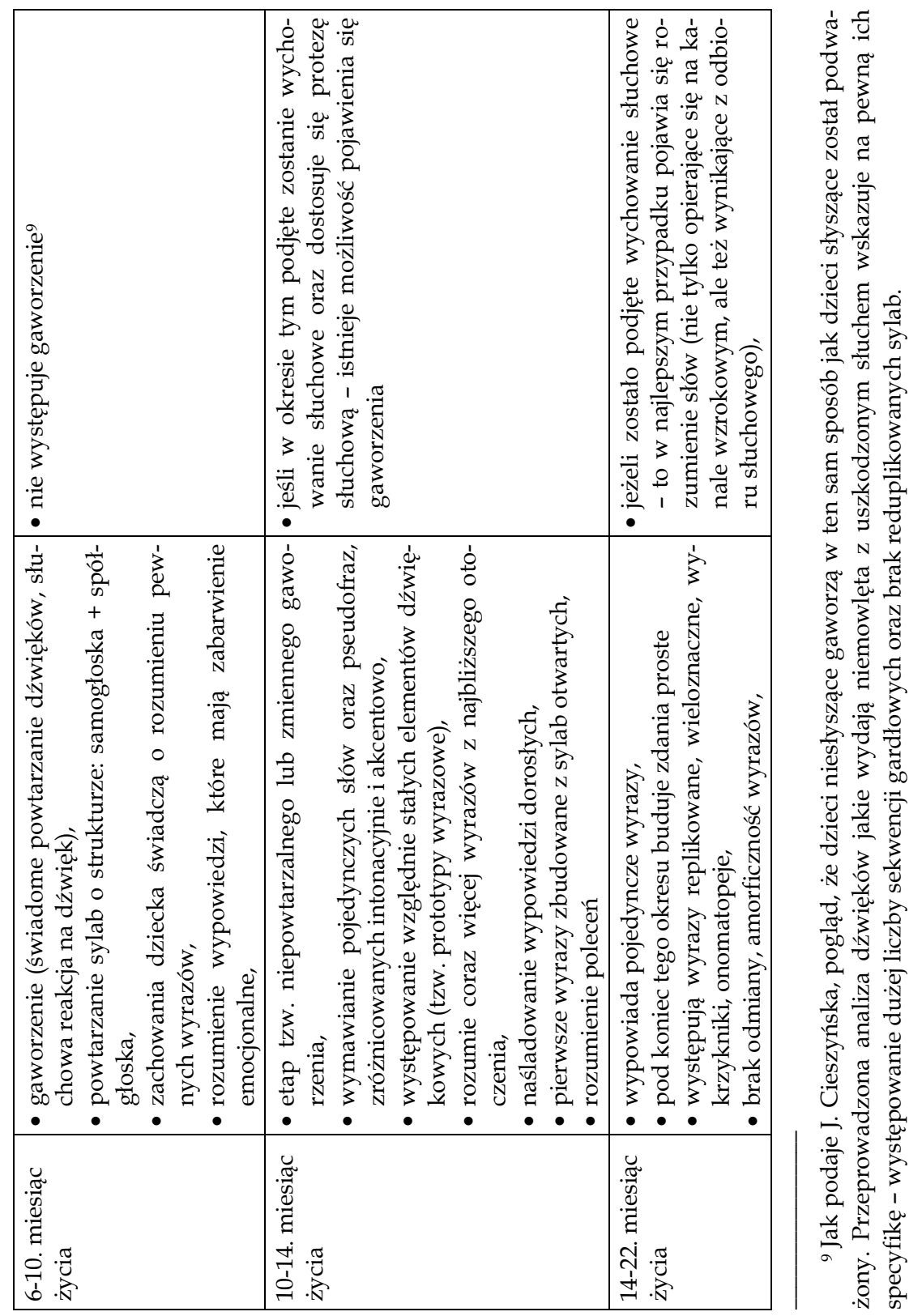




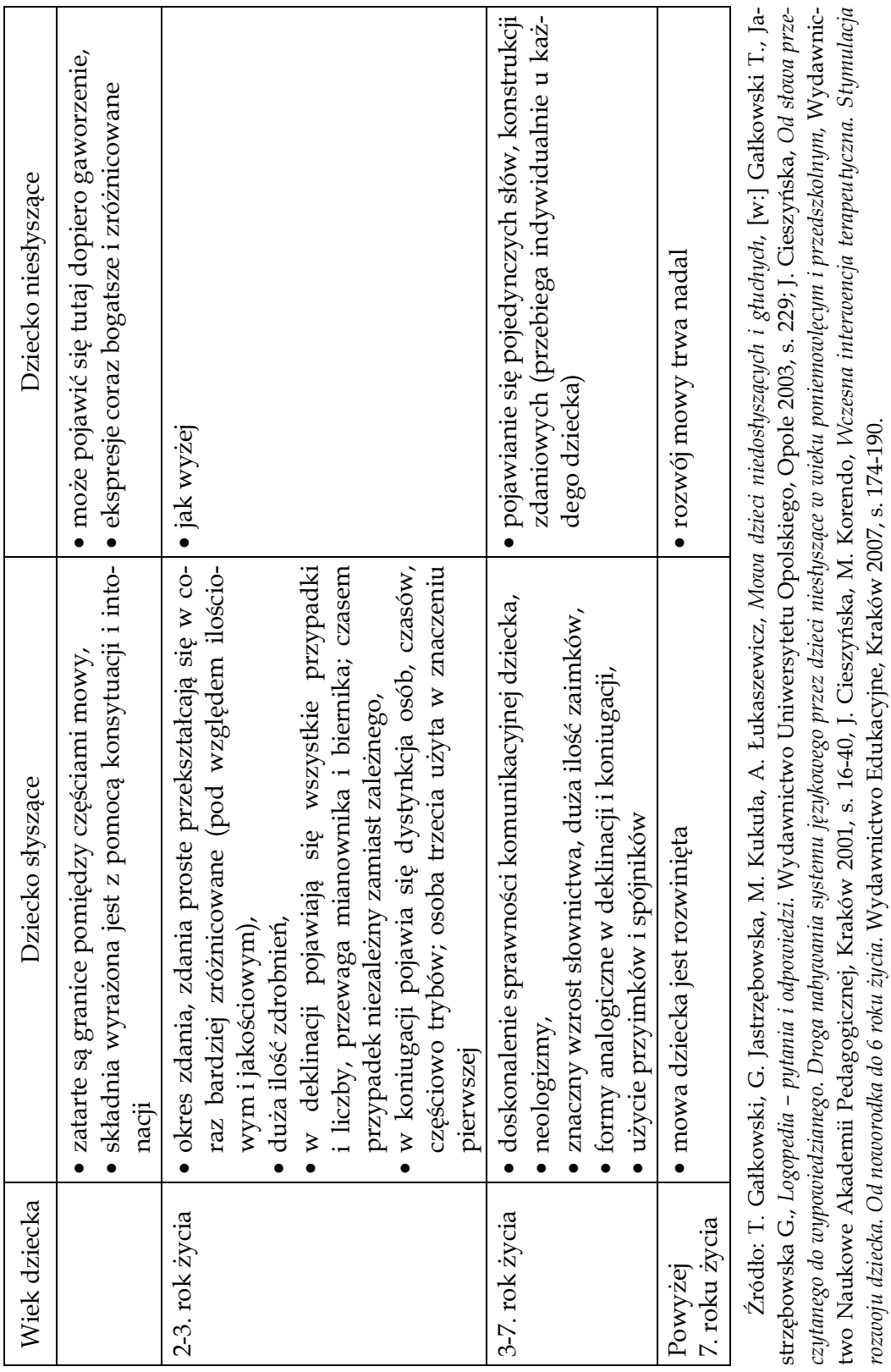


Jak potwierdzają liczne badania ${ }^{10}$ małe dzieci z uszkodzonym słuchem, także te $\mathrm{z}$ głębokim stopniem, dokonują wokalizacji, jednakże jej jakość a także pojawiający się repertuar fonemów i rozumienie mowy jest wynikiem dostępu dziecka do świata dźwięków. Badania wskazują także, że dzieci z głębokim uszkodzeniem słuchu nie gaworzą $\mathrm{w}$ tym samym czasie co słyszące czy też dzieci z niższym stopniem uszkodzenia słuchu ${ }^{11}$.

\section{Konsekwencje uszkodzenia słuchu}

Podstawowe konsekwencje uszkodzenia słuchu dotyczą ograniczeń lub całkowitej niemożności odbioru dźwięków z otoczenia. Jednakże wtórne skutki są bardziej złożone, szczególnie wtedy, gdy uszkodzenie słuchu nastąpiło $\mathrm{w}$ najbardziej wrażliwym okresie życia dla rozwoju mowy dziecka - od urodzenia do wczesnego dzieciństwa. Powodem tego jest fakt, że uszkodzenie słuchu powo-

10 Zob. m.in. C. Yoshinga-Itano, Development of audition and speech: Implications for early intervention with infants who are deaf or hard of hearing, "The Volta Review" 2000, nr 100, s. 181-212; C. Yoshinga-Itano, A.L. Sedley, Language, speech and socialemotional development of children who are deaf and hard-of-hearing: The early years, "The Volta Review" 2000, nr 100, s. 213-234; C. Yoshinga-Itano, Early identification, communication modality and the development of speech and spoken language skills: Patterns and considerations [w:] Advances in the spoken language development of deaf and hard-ofhearing children, red. P. Spencer, M. Marschark, Oxford University Press, New York 2006; D.K Oller, The emergence of the speech capacity, NJ: Erlbaum, Mahwah 2000; E. Hoff, Language development, Cengage Learning, CA: Wadsworth, Belmont 2008; T. Humphries, P. Kushalnagar, G. Mathur, D.J. Napoli, C. Padden, C. Rathmann, S.R. Smith, Language acquisition for deaf children: Reducing the harms of zero tolerance to the use of alternative approaches, "Harm Reduction Journal" $2012 \mathrm{~m}$ nr 9(1), s. 16.

11 Zob. m.in. R.E. Eilers, D.K. Oller, Infant vocalisations and the early diagnosis of severe hearing impairment, "Journal of Pediatrics" 1994, nr 124, s. 199-203; D.K. Oller, R.E. Eilers, The role of audition in infant babbling, "Child Development" 1988, nr 59, s. 441-449; T. Ching, K. Crowe, V. Martin, J. Day, N. Mahler, S. Youn, L. Street, C. Cook, J. Orsini, Language development and everyday functioning of children with hearing loss assessed at 3 years of age, "International Journal of Speech-Language Pathology" 2010, nr 12(2), s. 124-131. 
duje wystąpienie trzech aspektów deprywacji zmysłowej. Pierwszy związany jest ze zniszczeniem narządu będącego receptorem, drugi dotyczy pozbawienia lub ograniczenia dopływu bodźców charakterystycznych dla danej modalności zmysłowej, natomiast trzeci związany jest ze zmniejszeniem dopływu niespecyficznych stymulacji zmysłowych, wynikających z zubożenia globalnego środowiska. Ostatni z wymienionych aspektów deprywacji słuchowej jest szczególnie istotny dla rozwoju dziecka. Uszkodzony narząd słuchu pozbawia dziecko najsilniejszego bodźca rozwojowego, jakim jest dźwięk głosu ludzkiego, ograniczając tym samym zdolność do przyswajania mowy werbalnej12. Należy pamiętać, że każdy, nawet bardzo krótki okres prawidłowego działania słuchu umożliwia dziecku zdobycie pewnych doświadczeń, które mogą być pomocne w kształtowaniu się wyobrażeń i pojęć dotyczących dźwięków mowy, a stanowią podstawę dla systemu fonologicznego w umyśle dziecka13.

\section{Cechy mowy dziecka z uszkodzonym słuchem}

Eleonor L. Kaplan i George A. Kaplan ${ }^{14}$ dokonali klasyfikacji rozwoju języka dziecka na trzy okresy: prelingwistyczny, interlingwistyczny oraz postlingwistyczny. Poniża tabela zawiera charakterystyczne cechy rozwoju mowy dziecka z uszkodzonym narządem słuchu, uwzględniając powyższą klasyfikację.

Znaczne uszkodzenie słuchu powoduje, że niezbędne umiejętności do tworzenia samodzielnych wypowiedzi są u dziecka znacznie opóźnione. Opóźnienia te są zarówno ilościowe (zasób słownictwa

12 O. Perier, Dziecko z uszkodzonym narzadem stuchu. Aspekty medyczne, wychowawcze, socjologiczne i psychologiczne, WSiP, Warszawa 1992.

${ }^{13}$ K. Krakowiak, Dar języka. Podręcznik metodyki wychowania językowego dzieci i młodzieży z uszkodzeniami narządu stuchu, Wydawnictwo KUL, Lublin 2012.

14 Za: G. Dryżałowska, Rozwój językowy dziecka z uszkodzonym stuchem a integracja edukacyjna, model ksztatcenia integracyjnego, Wydawnictwo Uniwersytetu Warszawskiego, Warszawa 2007, s. 25-26. 
Tabela 2. Podział okresu rozwoju językowego według E.L. Kaplan i G.A. Kaplana

\begin{tabular}{|c|c|}
\hline $\begin{array}{c}\text { Okres rozwoju } \\
\text { mowy }\end{array}$ & Cechy rozwoju mowy dziecka z uszkodzonym słuchem \\
\hline 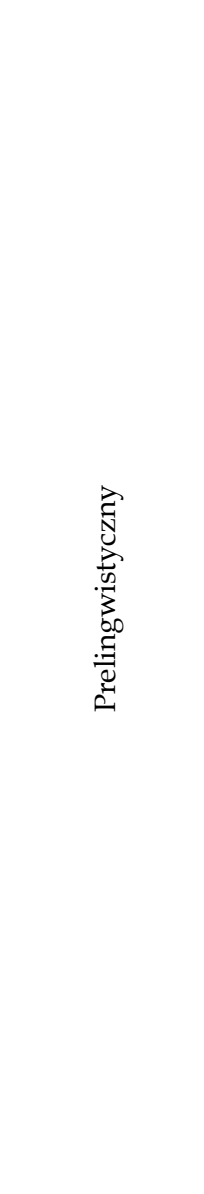 & $\begin{array}{l}\text { - } \text { różnice na poziomie pierwszych przejawów mowy są mało } \\
\text { widoczne, trudne do zauważenia dla rodziców, którzy nie mieli } \\
\text { takich doświadczeń, } \\
\text { - mniejsze zróżnicowanie wokalizacji, nieznaczne odchylenia } \\
\text { w długości, } \\
\text { - około 2-3. miesiąca dziecko wyraża swój pozytywny stan emo- } \\
\text { cjonalny za pomocą mimowolnie wydawanych dźwięków, bawi } \\
\text { się głosem (grucha), } \\
\text { - nie podejmuje prób produkcji samogłosek i spółgłosek, } \\
\text { - brak reakcji kołowych - dziecko nie słyszy tego, co produkuje - } \\
\text { nie prowokuje do podejmowania pierwszych naśladowczych } \\
\text { wokalizacji, łączenia samogłosek i spółgłosek w sylaby i ich } \\
\text { ciągi, } \\
\text { - nie pojawia się wczesny mechanizm kształtowania języka, } \\
\text { - dziecko nie gaworzy, nie jest w stanie naśladować intonacji } \\
\text { dorosłych } \\
\text { - dziecko jest pozbawione możliwości pełnozmysłowego odkry- } \\
\text { wania podstawowych funkcji języka; odkrywa je na drodze } \\
\text { kontaktu pozawerbalnego, } \\
\text { - system pojęć tworzony jest głównie na podstawie spostrzeżeń } \\
\text { wzrokowych, co powoduje brak pojęć semantycznych, które są } \\
\text { istotne w procesach uogólniania poznawanej rzeczywistości } \\
\text { oraz posługiwania się językiem, } \\
\text { - brak umiejętności posługiwania się pojęciami mającymi status } \\
\text { operacji ponadzmysłowej, } \\
\text { - rozumienie nie wyprzedza mowy, } \\
\text { - na drodze ćwiczeń artykulacyjnych, obserwacji warg osoby } \\
\text { mówiącej, dziecko podejmuje pierwsze próby posługiwania się } \\
\text { mową, } \\
\text { czierwszy okres rozwoju języka zostaje wykorzystany w ograni- } \\
\text { on zakresie }\end{array}$ \\
\hline 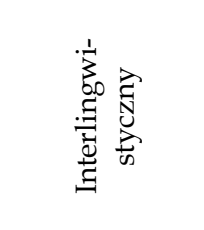 & $\begin{array}{l}\text { - wewnętrzne struktury są ukształtowane na poziomie niewy- } \\
\text { starczającym do opanowania pojęć, znaczeń, właściwości } \\
\text { przedmiotów oraz zjawisk, } \\
\text { - dziecko nie jest zdolne do prawidłowego wytwarzania dźwię- } \\
\text { ków, zapamiętywania ich oraz przypominania wcześniejszych } \\
\text { bodźców akustycznych, }\end{array}$ \\
\hline
\end{tabular}


cd. tab. 2

\begin{tabular}{|c|c|}
\hline $\begin{array}{c}\text { Okres rozwoju } \\
\text { mowy }\end{array}$ & Cechy rozwoju mowy dziecka z uszkodzonym słuchem \\
\hline 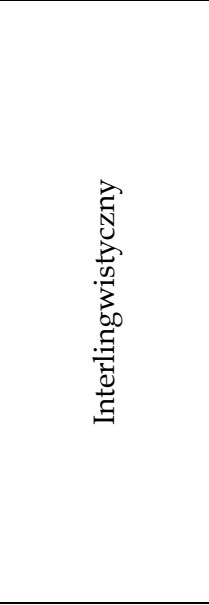 & $\begin{array}{l}\text { - dziecko nie jest w stanie w pełni kontrolować własnych wokali- } \\
\text { zacji (zaburzony system sprzężenia zwrotnego w zakresie na- } \\
\text { rządu słuchu), } \\
\text { - znaczne opóźnienie rozwoju językowego w stosunku do słyszą- } \\
\text { cych rówieśników, } \\
\text { - dziecko wymaga wielu ćwiczeń przy zapamiętaniu i zrozumie- } \\
\text { niu związku pomiędzy przymiotnikami a rzeczownikami, } \\
\text { - problem stanowi opanowanie koniugacji czasowników oraz } \\
\text { deklinacji rzeczowników (dziecko niesłyszące musi się jej nau- } \\
\text { czyć i zapamiętać); dziecko jest silnie związane z przedmiotem, } \\
\text { ma trudności w zrozumieniu, że nazwy ulegają zmianom za } \\
\text { względu na zmieniające się sytuacje, } \\
\text { - problem w rozumieniu znaczeń (kontekst, intonacja głosu, } \\
\text { rozłożone akcenty), } \\
\text { - nieumiejętność wykorzystania języka w rozwoju umysłowym } \\
\text { i społecznym }\end{array}$ \\
\hline 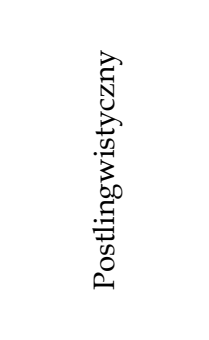 & $\begin{array}{l}\text { - uszkodzenie słuchu we wczesnych stadiach powoduje, że } \\
\text { w } 7 \text {. roku życia dziecko jest na poziomie niewystarczającym do } \\
\text { wkroczenia w okres postlingwistyczny, } \\
\text { - dziecko opanowuje podstawowe struktury języka w wieku } \\
12 \text { lat - gdy otrzyma właściwą pomoc w ich odkrywaniu i za- } \\
\text { pamiętywaniu, } \\
\text { - rozpoczynając naukę szkolną dziecko nie ma wystarczająco } \\
\text { opanowanego systemu językowego, nie jest zdolne do skutecz- } \\
\text { nego zdobywania wiedzy oraz jej przekazywania }\end{array}$ \\
\hline
\end{tabular}

Źródło: G. Dryżałowska, Rozwój jezzykowy dziecka z uszkodzonym słuchem a integracja edukacyjna, model ksztatcenia integracyjnego, Wydawnictwa Uniwersytetu Warszawskiego, Warszawa 2007, s. 25-37.

czynnego i biernego, kształtuje się poniżej wieku chronologicznego dziecka), jak i jakościowe (liczne, różne zaburzenia artykulacji, nieprawidłowości semantyczne, problemy z rozumieniem poleceń) ${ }^{15}$. Maria Góral ${ }^{16}$ zwraca uwage na charakterystyczne cechy mowy dzieci z wadą słuchu:

15 Ibidem.

16 M. Góral, Potrzeby wychowawcze małego dziecka głuchego, WSiP, Warszawa 1985. 
- odrębność w brzmieniu i modulacji - czego przyczyną jest niedostateczny odbiór słuchowy, a zmiany są tym poważniejsze im później dziecko otrzymało aparat słuchowy oraz im większy jest stopień uszkodzenia słuchu;

- błędy artykulacji dotyczące głosek, które znajdują się poza zakresem pola słuchowego dziecka (głoski o wysokich częstotliwościach);

- zaburzenia tempa i rytmu mowy występujące najczęściej u dzieci, z którymi późno rozpoczęto naukę mowy werbalnej;

- liczne agramatyzmy (dzieci z głębokim stopniem uszkodzenia słuchu nie uwzględniają zasad gramatycznych).

Jeśli jednak podczas oddziaływań rehabilitacyjnych uda się rozwinąć u dziecka mowę dźwiękową, może być ona obarczona różnymi, charakterystycznymi zaburzeniami dla osób z uszkodzonym narządem słuchu. Mogą one występować pojedynczo lub też jednocześnie. Są to:

- nieprawidłowe oddychanie - oddech jest za krótki lub nieekonomiczny ( $w$ trakcie mówienia wydychane jest zbyt wiele powietrza);

- głos jest zbyt niski lub zbyt wysoki, czasem może być chrapliwy lub piskliwy, monotonny, bez modulacji, czasami zbyt cichy, zbyt głośny o zmiennym natężeniu;

- artykulacja nieprawidłowa - zniekształceniu ulegają przede wszystkim głoski przednio- i środkowojęzykowe;

- system semantyczny - ograniczony zasób słowno-pojęciowy mowy, elizje, reduplikacje, zamiany głosek, dodawanie głosek wynikające $\mathrm{z}$ nieprawidłowej interpretacji gramatycznego zapisu słów lub też udźwięcznianie głosek w wygłosie;

- zaburzenia składni - posługiwanie się zdaniami prostymi, budowa zdań niezgodna z gramatyką języka polskiego (nakładanie się gramatyki języka migowego na gramatykę języka polskiego), częste stosowanie końcówek w przypadkowy sposób;

- tempo mowy - zmowa zazwyczaj zbyt powolna, rzadziej zbyt szybka; 
- brak akcentu wyrazowego oraz intonacji (często również akcentu wyrazowego oraz akcentowania pierwszej sylaby) ${ }^{17}$.

Jak pisze K. Krakowiak ${ }^{18}$, styl i język dzieci z uszkodzonym słuchem jest charakterystyczny ze względu na specyficzne ograniczenie doświadczenia językowego. Zalicza do nich: stosunkowo uboższy słownik (w porównaniu ze słyszącymi rówieśnikami); treść wyrazów ustalona jest na podstawie ograniczonej możliwości doświadczenia komunikacyjnego; bardzo niski zasób słownictwa specjalistycznego, literackiego oraz archaicznego; niski zasób słownictwa abstrakcyjnego, wynikający z braku doświadczenia, skłonności do tworzenia neologizmów; trudności w stylistycznej formie wyrazów, rozumieniu ich barwy emocjonalnej oraz wartości ekspresyjnej; trudności w ustalaniu metaforycznego znaczenia wyrazów; skłonność do tworzenia neologizmów i neosemantyzmów (sposób kompensacji niedoborów językowych); tendencja do ustalania znaczenia wyrazów tylko na podstawie ich morfologii; używanie słów w znaczeniu jakie przypisywane im jest poprzez znajomość znaków języka migowego; trudności w rozumieniu frazeologizmów; błędy gramatyczne w zakresie fleksji i składni; liczne skróty myślowe wynikające z przewagi percepcji wzrokowej; spójność tekstu oparta jest na wyobrażeniach przestrzennych; trudności w zachowaniu spójności czasowej elementów tekstu; trudność w przechodzeniu od mowy niezależnej do zależnej i odwrotnie.

17 Zob. B. Szczepankowski, Niestyszacy - głusi - głuchoniemi, WSiP, Warszawa 1999; T. Gold, Speech production in hearing-impaired children, "Journal of Communication Disorders" 1980, nr 13, s. 397-418; N. Tye-Murray, Articulatory organizational strategies and the roles of auditory information, "Volta Review" 1992, nr 94, s. 243-260; C. Formby, R.B. Monsen, Long-term average speech spectra for normal and hearingimpaired adolescents, "Journal of the Acoustical Society of America" 1982, nr 71, s. 196-202; V. Wallace, L. Menn, C. Yoshinga-Itano, Is babble the gateway to speech for all children? A longitudinal study of deaf and hard-of-hearing infants, "Volta Review" 2000, nr 100(5), s. 121-148.

${ }^{18}$ K. Krakowiak, Studia i szkice o wychowaniu dzieci z uszkodzeniami stuchu, Wydawnictwo KUL, Lublin 2006; Krakowiak K., Typologia zaburzeń mowy u osób z uszkodzonym stuchem, [w:] Surdologopedia. Teoria i praktyka, red. E. Muzyka-Furtak, Wydawnictwo Harmonia Universalis, Gdańsk 2015. 
Według Grażyny Guni19 rozwój dziecka słyszącego odbywa się w świecie dźwiękowo-obrazowym, natomiast dziecka z uszkodzonym słuchem w świecie obrazowo-dźwiękowym. U dziecka, u którego rozwój mowy nie był systematycznie rozwijany i kształcony, a przedmioty znajdujące się $\mathrm{w}$ otoczeniu nie były nazywane - nie dochodzi do kształtowania się mowy wewnętrznej, (która to stanowi zasób niezbędnych pojęć systemu leksykalnego) a w efekcie do ubogiego zasobu słownictwa i konkretnym nazywaniem rzeczy i zjawisk. Tezę tę potwierdzają badania Alicji Rakowskiej20 dotyczące rozwoju systemu gramatycznego dzieci niesłyszących. Analiza empiryczna wykazała, że w zasobie leksykalnym tej grupy dzieci dominują wyrazy nazywające prymarne - rzeczowniki i czasowniki. Rzeczowniki to głównie nazwy określające osoby, rzeczy, rośliny, zwierzęta z najbliższego otoczenia. Jak wskazują badania A. Rakowskiej, dzięki systematycznej rewalidacji prowadzonej w klasach młodszych, zakres znaczeń rzeczowników poszerza się, obejmując coraz więcej kategorii znaczeniowych. W zasobie słownictwa biernego i czynnego u dzieci z uszkodzonym słuchem występują zazwyczaj czasowniki odnoszące się do czynności, które wykonywane są kilka razy dziennie zarówno przez dzieci jak osoby im bliskie (czasowniki z grupy: toaleta, ubieranie się, spożywanie pokarmów itp. $)^{21}$. Trudności występujące z zakresie opanowywania systemu leksykalnego dotyczą również wyrazów sekundarnych (przymiotników i przysłówków), wskazujących (zaimki), szeregujących (liczebniki) oraz luźnych morfemów (spójniki, partykuły, przyimki). Do przymiotników jakimi najczęściej posługują się dzieci z uszkodzonym słuchem zalicza się wyrazy oznaczające barwę, kształt, ciężar i rozmiar - określające cechy sensoryczne, odbierane przez wrażenia zmysłowe. Rzadko poja-

${ }^{19}$ G. Gunia, Terapia logopedyczna dzieci z zaburzeniami stuchu i mowy. Wybrane problemy teorii i praktyki surdologopedycznej, Oficyna Wydawnicza „Impuls”, Kraków 2006.

20 A. Rakowska, Rozwój systemu gramatycznego u dzieci głuchych, Wydawnictwo Naukowe WSP, Kraków 1995.

${ }^{21}$ G. Gunia, Stownictwo czynne i bierne dzieci głuchych kończących szkołę podstawo$w q$, Rocznik Naukowo-Dydaktyczny, z. 100, „Prace Pedagogiczne” VI, WN, WSP, Kraków 1986. 
wiają się natomiast przymiotniki oceniające i wartościujące. Najczęściej w mowie dziecka z uszkodzonym słuchem pojawiają się przysłówki, które określają miejsce (tu, tutaj, tam) oraz przysłówki oznaczające czas i sposób wykonania czynności. Najczęściej używanymi zaimkami są: zaimek osobowy - „ja” oraz dzierżawczy „mój” (mają one dla dziecka konkretne znaczenie). Ze względu na fakt, że wypowiedzi dzieci stanowią zazwyczaj zdania proste - spójniki używane są rzadko. Natomiast wśród partykuł najczęściej używane są dwie „nie" i „czy”22. Badania dotyczące znajomości przyimków wskazały, że dzieci z uszkodzonym słuchem prawie nie używają przyimka w zdaniu, nadają im znaczenie rzeczownikowe, rozumieją tylko niektóre przyimki (w konkretnym znaczeniu), nie rozumieją ich abstrakcyjnego znaczenia oraz mają problemy z ujmowaniem przyimka do określenia stosunku pomiędzy dwoma przedmiotami ${ }^{23}$. Wystąpienie uszkodzenia słuchu skutkuje także trudnościami w przyswajaniu słów oraz ich znaczeń. Zasób słownictwa dzieci słabosłyszących i niesłyszących charakteryzuje się swoistymi ograniczeniami - ilościowymi i jakościowymi. Wzrost zasobu leksykalnego następuje powoli i stopniowo, zależy od szeregu czynników. Uszkodzenie słuchu stanowi przeszkodę $\mathrm{w}$ procesie naturalnego nabywania reguł słowotwórczych. Dzieci mają trudności $\mathrm{z}$ dostrzeżeniem relacji formalno-semantycznych pomiędzy wyrazami, a niski poziom świadomości budowy słowotwórczej wyrazów oraz ich wzajemnej pochodności prowadzi do braku rozumienia znaczeń konstrukcji słowotwórczych, a także trudności z ich przyswajaniem. W rozwoju językowym dziecka z uszkodzonym słuchem kształtowanie się podstaw słowotwórstwa przebiega z opóźnieniem, a trudności w tym zakresie pojawiają się także wśród niesłyszących i słabosłyszących uczniów klas starszych ${ }^{24}$.

22 G. Gunia, Terapia logopedyczna dzieci...; R. Kołodziejczyk, Trudności gramatyczne u dzieci i młodzieży z uszkodzeniami stuchu, [w:] Surdologopedia. Teoria i...

${ }^{23}$ L. Geppert, Źródła trudności w przyswajaniu języka przez dzieci głuche, PWN, Warszawa 1968.

${ }^{24}$ E. Muzyka-Furtak, Wyrazy pochodne w słowniku dzieci z uszkodzeniami stuchu, [w:] Surdologopedia. Teoria i... 
Podobne wyniki badań uzyskał Zdzisław Kurkowski25, dowodząc, że istnieją znaczne zróżnicowania w opanowywaniu słownictwa przez dzieci sześcioletnie, z uszkodzonym słuchem. Jak wskazuje autor, $11,5 \%$ dzieci nie używało w ogóle słów, natomiast 7,7\% wypowiedziało tylko formy cząstkowe wyrazów lub też leksemy ekspresywno-onomatopeiczne. Jak podkreśla Z. Kurkowski, żadne $\mathrm{z}$ badanych dzieci nie osiągnęło zasobu słownictwa biernego i czynnego takiego, jakie jest charakterystyczne dla sześciolatka, natomiast większość dzieci opanowała poziom rozwoju mowy trzylatka.

Badania Ewy Muzyki26 dotyczące komunikacyjnej sprawności społecznej dzieci z prelingwalnym uszkodzeniem słuchu, w trzech sytuacjach komunikacyjnych (wchodzenie w kontakt społeczny, podtrzymanie kontaktu, wzbogacanie kontaktu) dowiodły, że uczniowie niesłyszący $\mathrm{w}$ realizacji danych komunikacyjnych aktów społecznych napotykają na trudności związane z: ograniczonym zasobem formuł grzecznościowych, brakiem umiejętności praktycznego zastosowania formuł, rozszerzaniem zakresu znaczeniowego znanych konstrukcji, brakiem wiedzy dotyczącej ograniczeń $\mathrm{w}$ zakresie użycia formuł komunikacyjnych, nadużywaniem formuł społecznie nieograniczonych i uniwersalnych, odróżnianiem konstrukcji formalnych i nieformalnych, ograniczeniami w zakresie budowania wypowiedzi, zwłaszcza $\mathrm{w}$ przypadku nierównorzędnych rangą rozmówców, nieznajomością konotacji składniowej czasowników, które wchodzą w skład formuł grzecznościowych oraz $\mathrm{z}$ brakiem umiejętności formułowania wypowiedzi jako całości. Nabywanie kompetencji komunikacyjnej dzieci z uszkodzonym słuchem stanowiło przedmiot analizy empirycznej A. Rakowskiej ${ }^{27}$. Analizowana tutaj była umiejętność posługiwania się znakami ko-

${ }^{25}$ Z.M. Kurkowski, Mowa dzieci sześcioletnich z uszkodzonym narządem stuchu, Wydawnictwo UMCS, Lublin 1996, s. 182-183.

${ }^{26}$ E. Muzyka, Komunikacyjna sprawność społeczna dzieci niestyszacych, „Polonistyka" 2003, t. 32, s. 139-155.

27 A. Rakowska, Jak porozumiewaja się dzieci niestyszace z osobami styszacymi, Wydawnictwo Naukowe Akademii Pedagogicznej, Kraków 2000. 
munikacyjnymi w zakresie sytuacji zabawowo-zadaniowej przez dzieci w wieku przedszkolnym. Zdaniem autorki, w społecznej aktywności dzieci z uszkodzonym słuchem występują trzy rodzaje komunikowania się:

- komunikacja niewerbalna,

- komunikacja werbalno-niewerbalna,

- komunikacja werbalna.

Według A. Rakowskiej podstawowe znaczenie dla rozwoju umiejętności komunikacyjnych i językowych dzieci niesłyszących ma okres dzieciństwa. Wczesne doświadczenia dziecka, a zwłaszcza świadomość i jakość oddziaływań rodziców mają znaczny wpływ na późniejsze sposoby komunikacji.

Jak pisze Z. Kurkowski28, umiejętność językowego porozumiewania się stanowi istotną zdolność dziecka z uszkodzonym narządem słuchu. Umiejętność ta ma wpływ na wybór odpowiedniej szkoły oraz metody nauczania. Nie można jej traktować jako odrębnej funkcji, ponieważ jest powiązana $z$ innymi funkcjami i razem tworzą nierozerwalną całość. Intensywna rehabilitacja mowy od najwcześniejszego okresu życia dziecka z uszkodzonym narządem słuchu daje możliwość pokonania problemów rozwoju mowy werbalnej.

\section{Zakończenie}

Analizując możliwości komunikacyjne dzieci z uszkodzonym narządem słuchu, śmiało można stwierdzić, że słuchowa droga nabywania i posługiwania się językiem jest zaburzona i uzależniona od wielu czynników. Ponadto utrudnienia w percepcji i wokalizacji dźwięków mogą powodować znaczne opóźnienia w rozwoju mowy. Przejawiają się one w później pojawiającym się gaworzeniu lub całkowitym jego braku, w późniejszym wypowiadaniu pierwszych

28 Z.M. Kurkowski, Mowa dzieci sześcioletnich z uszkodzonym narządem stuchu, Wydawnictwo UMCS, Lublin 1996. 
słów, w mniejszym zasobie słownika mowy czynnej i biernej, w późniejszym pojawianiu się zdań oraz w dłuższym występowaniu nieprawidłowych struktur gramatycznych. Rozwój mowy i komunikacji dziecka z uszkodzonym słuchem stanowi bardzo złożony proces, uwarunkowany szeroką grupą czynników m.in.: biologicznych, środowiskowych, psychologicznych. Warto zauważyć, że dzięki współczesnym osiągnięciom medycyny, techniki, a przede wszystkim dzięki świadomości i wiedzy specjalistów i rodziców, dziecko z uszkodzonym słuchem ma znacznie większe możliwości na osiągnięcie wyższego poziomu kompetencji językowej i komunikacyjnej.

\section{Bibliografia}

Anderson J., Reilly J., The MacArthur Communicative Development Inventory: The normative data from American Sign Language, "Journal of Deaf Studies and Deaf Education" 2002, nr 7.

Ching T., Crowe K., Martin V., Day J., Mahler N., Youn S., Street L., Cook C., Orsini J., Language development and everyday functioning of children with hearing loss assessed at 3 years of age, "International Journal of Speech-Language Pathology" 2010, $\mathrm{nr} 12(2)$.

Cieszyńska J., Od stowa przeczytanego do wypowiedzianego. Droga nabywania systemu językowego przez dzieci niestyszace w wieku poniemowlęcym i przedszkolnym, Wydawnictwo Naukowe Akademii Pedagogicznej, Kraków 2001.

Cieszyńska J., Wczesna nauka czytania jako stymulacja rozwoju dzieci niestyszacych, [w:] Ku wspólnocie komunikacyjnej niestyszacych $i$ styszacych, red. K. Krakowiak, A. Dziurda-Multan, Wydawnictwo KUL, Lublin 2011.

Cieszyńska J., Korendo M., Wczesna interwencja terapeutyczna. Stymulacja rozwoju dziecka. Od noworodka do 6 roku życia, Wydawnictwo Edukacyjne, Kraków 2007.

Cormier K., Schembri A., Vinson D., Orfanidou E., First language acquision differs from second language acquisition in prelingually deaf signers: Evidence from sensitivity to grammaticality judgement in British Sign Language, "Cognition" 2012, nr 124.

Dryżałowska G., Rozwój językowy dziecka z uszkodzonym stuchem a integracja edukacyjna, model kształcenia integracyjnego, Wydawnictwa Uniwersytetu Warszawskiego, Warszawa 2007.

Eilers R.E., Oller D.K., Infant vocalisations and the early diagnosis of severe hearing impairment, "Journal of Pediatrics" 1994, nr 124. 
Formby C., Monsen R.B., Long-term average speech spectra for normal and hearingimpaired adolescents, "Journal of the Acoustical Society of America" 1982, nr 71.

Gałkowski T., Jastrzębowska G., Kukuła M., Łukaszewicz A., Mowa dzieci niedosłyszacych i głuchych, [w:] Gałkowski T., Jastrzębowska G., Logopedia - pytania i odpowiedzi, Wydawnictwo Uniwersytetu Opolskiego, Opole 2003.

Geppert L., Źródta trudności w przyswajaniu języka przez dzieci głuche, PWN, Warszawa 1968.

Gold T., Speech production in hearing-impaired children, "Journal of Communication Disorders" 1980, nr 13.

Góral M., Potrzeby wychowawcze małego dziecka głuchego, WSiP, Warszawa 1985.

Gunia G., Stownictwo czynne i bierne dzieci głuchych kończacych szkołe podstawowa, Rocznik Naukowo-Dydaktyczny WSP, z. 100, "Prace Pedagogiczne”, VI, WN, WSP, Kraków 1986.

Gunia G., Terapia logopedyczna dzieci z zaburzeniami stuchu i mowy. Wybrane problemy teorii $i$ praktyki surdologopedycznej, Oficyna Wydawnicza „Impuls”, Kraków 2006.

Hoff E., Language development, Cengage Learning, CA: Wadsworth, Belmont 2008.

Humphries T., Kushalnagar P., Mathur G., Napoli D.J., Padden C., Rathmann C., Smith S.R., Language acquisition for deaf children: Reducing the harms of zero tolerance to the use of alternative approaches, "Harm Reduction Journal" 2012, nr 9(1).

Humphries T., Kushalnagar P., Mathur G., Napoli D.J., Padden C., Rathmann C., Smith S.R., Ensuring language acquisition for deaf children: What linguists can do, "Language" 2014, nr 90 (2).

Kołodziejczyk R., Trudności gramatyczne u dzieci i młodzieży z uszkodzeniami słuchu, [w:] Surdologopedia. Teoria i praktyka, red. E. Muzyka-Furtak Harmonia Universalis, Gdańsk 2015.

Krakowiak K., Bariery ksztatcenia językowego dzieci z głęboko uszkodzonym stuchem, [w:] Gtuchota a język, seria: Komunikacja językowa i jej zaburzenia, red. S. Grabias, Wydawnictwo UMCS i PZG, Lublin 1994.

Krakowiak K., O potrzebie pomocy dla rodzin wychowujacych dzieci z uszkodzeniami stuchu, [w:] Rodzina: źródło życia i szkoła miłości, red. D. Kornas-Biela, Towarzystwo Naukowe Katolickiego Uniwersytetu Lubelskiego, Lublin 2001.

Krakowiak K., Studia i szkice o wychowaniu dzieci z uszkodzeniami stuchu, Wydawnictwo KUL, Lublin 2006.

Krakowiak K., Dar języka. Podręcznik metodyki wychowania językowego dzieci i młodzieży z uszkodzeniami narzadu stuchu, Wydawnictwo KUL, Lublin 2012.

Krakowiak K., Typologia zaburzeń mowy u osób z uszkodzonym stuchem, [w:] Surdologopedia. Teoria i praktyka, red. E. Muzyka-Furtak, Wydawnictwo Harmonia Universalis, Gdańsk 2015.

Kurcz I., Psychologia jezyka i komunikacji, Wydawnictwo Naukowe Scholar, Warszawa 2000 . 
Kurkowski Z.M., Mowa dzieci sześcioletnich z uszkodzonym narządem stuchu, Wydawnictwo UMCS, Lublin 1996.

Muzyka E., Komunikacyjna sprawność społeczna dzieci niestyszacych, „Polonistyka” 2003, t. 32.

Muzyka-Furtak E., Wyrazy pochodne w stowniku dzieci z uszkodzeniami stuchu, [w:] Surdologopedia. Teoria i praktyka, red. E. Muzyka-Furtak E., Wydawnictwo Harmonia Universalis, Gdańsk 2015.

Oller D.K., The emergence of the speech capacity, NJ, Erlbaum, Mahwah 2000.

Oller D.K., Eilers R.E., The role of audition in infant babbling, "Child Development" 1988, nr 59.

Porayski-Pomsta J., O rozwoju mowy dziecka. Dwa studia, Dom Wydawniczy Elipsa, Warszawa 2015.

Rakowska A., Rozwój systemu gramatycznego u dzieci głuchych, Wydawnictwo Naukowe WSP, Kraków 1995.

Rakowska A., Jak porozumiewają się dzieci niestyszące z osobami styszącymi, Wydawnictwo Naukowe Akademii Pedagogicznej, Kraków 2000.

Supplement to the JCIH 2007 Position Statement: Principles and Guidelines for Early Intervention After Confirmation That a Child Is Deaf or Hard of Hearing, "American Academy of Pediatric, Pediatrics" 2013, vol. 131, nr 4.

Szczepankowski B., Niestyszacy - głusi-głuchoniemi, WSiP, Warszawa 1999.

Tye-Murray N., Articulatory organizational strategies and the roles of auditory information, "Volta Review" 1992, nr 94.

Wallace V., Menn L., Yoshinga-Itano C., Is babble the gateway to speech for all children? A longitudinal study of deaf and hard-of-hearing infants, "Volta Review" 2000, nr 100(5).

Woolfe T., Herman R., Roy P., Woll B., Early vocabulary development in deaf native signers: a British Sign Language adaptation of the communicative development inventories, "Journal of Child Psychology and Psychiatry" 2010, nr 51.

Year 2007 Position Statement: Principles and Guidelines for Early Hearing Detection and Intervention Programs Joint Committee on Infant Hearing, American Academy of Pediatric, "Pediatrics" 2007, vol. 120, nr 4.

Yoshinga-Itano C., Development of audition and speech: Implications for early intervention with infants who are deaf or hard of hearing [w:] Yoshinga-Itano C., Sedley A.L. Language, speech and social-emotional development of children who are deaf and hardof-hearing: The early years, "The Volta Review" 2000, nr 100.

Yoshinga-Itano C., Early identification, communication modality and the development of speech and spoken language skills: Patterns and considerations, [w:] Advances in the spoken language development of deaf and hard-of-hearing children, red. P. Spencer, M. Marschark, Oxford University Press, New York 2006. 